\title{
Premarital Sex Behaviors Among College Youths of Kathmandu, Nepal $\mathrm{BC} \mathrm{GB},{ }^{1}$ Basel PL ${ }^{2}$
}

\author{
${ }^{1}$ Department of Health Services, Ministry of Health \\ and Population, Government of Nepal \\ ${ }^{2}$ Department of Community Medicine and Public \\ Health (DCMPH), Institute of Medicine (IoM)
}

\section{Corresponding Author}

Gyan Bahadur BC

Department of Health Services, Ministry of Health and Population, Government of Nepal

Email: gyan_skt@yahoo.com

\section{Citation}

BC GB, Basel PL. Premarital Sex Behaviors Among College Youths of Kathmandu, Nepal. Kathmandu Univ Med J 2013;41(1):27-31.

\begin{abstract}
\section{Backgroud}

Unhealthy premarital sex behavior leads to several health problems namely; sexually transmitted diseases (STDs), Human Immune Virus and Acquired Immune Deficiency Syndrome (HIV/AIDS), unwanted pregnancies, abortions and maternal deaths. Unwanted pregnancies and unsafe abortions are rampant in Nepal despite introduction of legal provision for safe abortion since 2003. Lately, unsafe sex and sex without condoms and drinking before sex is increasing in trend in youth population. The primary aim of this study was to explore the factors associated with premarital sex behaviors.
\end{abstract}

\section{Objectives}

The main objective of the study was to identify the premarital sex behaviors and related factors among college youths in Kathmandu, Nepal.

\section{Methods}

Descriptive and explorative study of size 230 college youths aged between 1824 years. Data were collected by self-administered questionnaire from February 26 to March 15, 2012. The reliability of the questionnaire was ensured by using Cronbach's alpha.

\section{Results}

Late youths of age 20-24 were more likely to experience premarital sex than early youths of age 18-19 years old. Urban youths were less involved in premarital sex behavior than rural youth. Youths having negative attitudes towards premarital sex were more likely to experience premarital sex than a positive attitude. Youths who had good relationship with their parents had less premarital sex experience than youths having poor relationship with their parents.

\section{Conclusion}

One fifth of college youth had premarital sex experience where alcohol drinker had higher premarital sex experience than non-drinker. Youths having good peer norms were significantly less likely to experience premarital sex behaviors than youths having poor peer norms.

\section{KEY WORD}

Alcohol drinking, college youths, Nepal, peer norms, premarital sex 


\section{INTRODUCTION}

Premarital sex behavior is the sexual activity between two people who are not married. This behavior may lead several health problems namely sexually transmitted diseases (STDs), Human Immune Virus and Acquired Immune Deficiency Syndrome (HIV/AIDS), unwanted pregnancies, unsafe abortions and maternal deaths. ${ }^{1}$ Premarital sex is culturally and socially not accepted in country like Nepal. The more vulnerable group is unmarried youths and has higher risk of getting STDs and HIV infection. ${ }^{2}$

Previous several studies have shown factors related to premarital sex in three interfaces. First, at individual level, which includes demographic factors like age, sex, ethnicity secondly, at family level like family type, family income, occupation and thirdly at institutional level like social network, policies, laws etc. ${ }^{3}$ This study aimed to identify the factors related to premarital sex behaviors among college youths. This in turn will help the programmer to develop appropriate interventions to practice safer sex and reduce maternal deaths at large.

\section{METHODS}

This was a cross sectional descriptive study conducted at Kathmandu district from February 26 to March 15, 2012. The ethical approval was taken from the Ethical Review Committee for Human Research, Faculty of Public Health, Mahidol University (MUPH 2012-033). Verbal informed consent was taken from each participant. The study population was college youths of age 18-24 years currently studying in certificate/diploma or bachelor level comprising both sex either married or unmarried or divorced. Youths who was unable to answer the questions completely and those who were absent during data collection were excluded from the study.

By taking confidence interval of $95 \%$ and permissible error of 0.07 and "P" as 0.39 the number of sample size was 230 (This also includes $20 \%$ missing and incomplete data of the total sample size required).

The sampling unit was college youth of 18-24 years of age studying in 235 colleges in Kathmandu district. Two stages of sampling techniques were used. First 235 colleges were stratified into three categories namely large, medium and small size. Secondly, one college from each category was selected randomly. To meet the required sample size of 230 , the sample was drawn proportional to the size of large, medium and small category college. Therefore, 115, 77 and 38 students were picked up from large, medium and small category college respectively. Finally almost equal number of students was randomly selected within $1^{\text {st }}, 2^{\text {nd }}$ and $3^{\text {rd }}$ year program from each category of selected college.

Data collection was done by supplying anonymous selfadministered questionnaire to the youths only after clearly explaining the objective of the study, maintaining confidentiality and providing clear instruction to fill out the form. Most of the questions were both open and closed type however, behavioral pattern were measured by applying five rating scale. For rating scale seven statements comprising both positive and negative statements were asked where the maximum score was 35 and the minimum score was 7. Therefore, Median was used for cutoff point to segregate between two behavioral levels. The questionnaire was pretested among 30 college youths of Kathmandu for reliability by using Cronbach's Alpha, where the $\alpha$-coefficient was more than 0.7 .

Data were coded, edited and entered into SPSS 18 version. Further data cleaning, sorting and rechecking were done to maintain the quality. Summary table for descriptive statistics like mean, median, range and standard deviation were made. Chi-square test was used to test for association.

\section{RESULTS}

\section{Individual factors for premarital sex behaviors}

Late youths of age $20-24$ were more likely $(27.8 \%)$ to experience premarital sex than early youths $(13.5 \%)$ of age $18-19$ years old. Male were more likely (44.8\%) to be involved in premarital sex than female (4.2\%). Slightly more than $18 \%$ of Aryan ethnic youth were involved in premarital sex behaviors than Mongolian youths. Among the total religious belief nearly $19.6 \%$ of youths were involved in premarital sex behavior. Youths having good GPA (Grade Point Average) not necessarily had less premarital sex experience than fair and poor GPA. Category wise urban youths were less involved in premarital sex behavior than rural youth ( $16 \%$ Vs $28.4 \%$ ) however, among the total respondents $(n=230)$ urban youths were more involved in premarital sex behavior than rural youths $(11.3 \%$ Vs 8.3\%). Youths who drink and get involved in premarital sex behavior is much higher (34.6\%) than youths who do not drink (7.1\%) but get involved in premarital sex behavior. Youths having negative attitudes towards premarital sex were more likely to experience premarital sex than a positive attitude as shown in table 1.

\section{Family factors for premarital sex behaviors}

Under the family factors the following variables were assessed namely; living arrangement, family income, parental education and occupation, and relationship with parents. Youths who had good relationship with their parents had less premarital sex experience than youths having poor relationship with their parents $(19.4 \%$ Vs $24.4 \%)$. Relationship of youths with their parents were assessed by using five rating scale. Those who scored more than 26 were categorized under good relationship and those who scored less than or equal to 26 from the median value were categorized under poor relationship as shown in table 2. 
Table 1. Premarital sex behaviors by individual factors.

\begin{tabular}{|c|c|c|c|c|}
\hline \multicolumn{5}{|c|}{ Premarital sex behaviors } \\
\hline $\begin{array}{l}\text { Individual Fac- } \\
\text { tors }\end{array}$ & Yes & No & $X^{2}(d f)$ & p-value \\
\hline Age & & & $7.290(1)$ & 0.007 \\
\hline $18-19$ & $18(13.5 \%)$ & $115(86.5 \%)$ & & \\
\hline $20-24$ & $27(27.8 \%)$ & $70(72.2 \%)$ & & \\
\hline Sex & & & $56.74(1)$ & $<0.001$ \\
\hline Male & $39(44.8 \%)$ & $8(55.2 \%)$ & & \\
\hline Female & $6(4.2 \%)$ & $137(95.8 \%)$ & & \\
\hline Ethnic group & & & $0.043(1)$ & 0.836 \\
\hline Aryan & $42(19.7 \%)$ & $171(80.3 \%)$ & & \\
\hline Mongolian & $3(17.6 \%)$ & $14(82.4 \%)$ & & \\
\hline Religion group & & & $0.033(1)$ & 0.856 \\
\hline Hindu & $42(19.4 \%)$ & $174(80.6 \%)$ & & \\
\hline $\begin{array}{l}\text { Buddhist/Chris- } \\
\text { tian }\end{array}$ & $3(21.4 \%)$ & $11(78.6 \%)$ & & \\
\hline GPA & & & $0.068(2)$ & 0.966 \\
\hline Good & $10(20.8 \%)$ & $38(79.2 \%)$ & & \\
\hline Fair & $25(19.1 \%)$ & $106(80.9 \%)$ & & \\
\hline Poor & 10(19.6\%) & $41(80.4 \%)$ & & \\
\hline Class & & & $0.491(1)$ & 0.484 \\
\hline Diploma & $9(23.7 \%)$ & $29(76.3 \%)$ & & \\
\hline Bachelor & $36(18.8 \%)$ & $156(81.3 \%)$ & & \\
\hline Residence & & & $4.645(1)$ & 0.031 \\
\hline Urban & $26(16 \%)$ & $137(84 \%)$ & & \\
\hline Rural & $19(28.4 \%)$ & $48(71.6 \%)$ & & \\
\hline Alcohol drinking & & & $27.324(1)$ & $<0.001$ \\
\hline Drink & $36(34.6 \%)$ & $68(65.4 \%)$ & & \\
\hline Not drink & $9(7.1 \%)$ & $117(92.9 \%)$ & & \\
\hline Attitude & $5(5.2 \%)$ & $91(84.8 \%)$ & $21.582(1)$ & $<0.001$ \\
\hline Positive (>21) & $40(29.9 \%)$ & $94(70.1 \%)$ & & \\
\hline Negative $(\leq 21)$ & $21 \pm 4.07$ & & & \\
\hline Median $\pm S D$ & & & & \\
\hline Min-Max & $12-31$ & & & \\
\hline
\end{tabular}

Table 3. Premarital sex behaviors by peer factors in terms of peer norms.

\begin{tabular}{|lllll|}
\multicolumn{5}{c}{ Premarital sex behaviors } \\
Peer Factors & Yes & No & $X^{2}(\mathrm{df})$ & p-value \\
\hline Peer norms & & & $22.377(1)$ & $<0.001$ \\
\hline Good $(>24)$ & $6(5.8 \%)$ & $97(94.2 \%)$ & & \\
\hline Poor $(\leq 24)$ & $39(30.7 \%)$ & $88(69.3 \%)$ & & \\
\hline Median \pm SD & $24 \pm 5.34$ & & & \\
\hline Min-Max & $8-35$ & & & \\
\hline
\end{tabular}

\section{Peer factors for premarital sex behavior}

Youths who had good peer norms were significantly less likely to experience premarital sex behaviors than youths who had poor peer norms (5.8\% Vs $30.7 \%$ ). Peer norms were analyzed by categorizing into good and poor norms. For this rating scale was used and those who scored more
Table 2. Premarital sex behaviors by family factors

\begin{tabular}{|c|c|c|c|c|}
\hline \multicolumn{5}{|c|}{ Premarital sex behaviors } \\
\hline Family Factors & Yes & No & $X^{2}(d f)$ & p-value \\
\hline \multicolumn{3}{|c|}{ Living arrangement } & $0.887(1)$ & 0.346 \\
\hline With parents & $37(18.6 \%)$ & $162(81.4 \%)$ & & \\
\hline $\begin{array}{l}\text { Without } \\
\text { parents }\end{array}$ & $8(25.8 \%)$ & $23(74.2 \%)$ & & \\
\hline \multicolumn{3}{|l|}{ Family Income } & $0.902(1)$ & 0.342 \\
\hline $\begin{array}{l}\text { Moderate and } \\
\text { poor }\end{array}$ & $23(17.4 \%)$ & $109(82.6 \%)$ & & \\
\hline Rich & $22(22.4 \%)$ & $76(77.6 \%)$ & & \\
\hline \multicolumn{3}{|c|}{ Father's education } & $3.400(2)$ & 0.183 \\
\hline $\begin{array}{l}\text { No school/ } \\
\text { Primary }\end{array}$ & $9(20.5 \%)$ & $35(79.5 \%)$ & & \\
\hline $\begin{array}{l}\text { Secondary } \\
\text { education }\end{array}$ & $20(25.6 \%)$ & $58(74.4 \%)$ & & \\
\hline $\begin{array}{l}\text { Diploma/Uni- } \\
\text { versity }\end{array}$ & $16(14.8 \%)$ & $92(85.2 \%)$ & & \\
\hline \multicolumn{3}{|c|}{ Mother's education } & $0.048(2)$ & 0.976 \\
\hline $\begin{array}{l}\text { No school/ } \\
\text { Primary }\end{array}$ & $42(19.4 \%)$ & $100(80.0 \%)$ & & \\
\hline $\begin{array}{l}\text { Secondary } \\
\text { education }\end{array}$ & $3(21.4 \%)$ & $54(80.6 \%)$ & & \\
\hline $\begin{array}{l}\text { Diploma/Uni- } \\
\text { versity }\end{array}$ & $7(18.4 \%)$ & $31(81.6 \%)$ & & \\
\hline \multicolumn{3}{|c|}{ Father's occupation } & $1.926(2)$ & 0.382 \\
\hline $\begin{array}{l}\text { No salary } \\
\text { group }\end{array}$ & $16(22.9 \%)$ & $54(77.1 \%)$ & & \\
\hline Business group & $13(22.8 \%)$ & $44(77.2 \%))$ & & \\
\hline Salary group & $16(15.5 \%)$ & $87(84.5 \%)$ & & \\
\hline \multicolumn{3}{|c|}{ Mother's occupation } & $0.883(2)$ & 0.643 \\
\hline $\begin{array}{l}\text { No salary } \\
\text { group }\end{array}$ & $38(19.6 \%)$ & $156(80.4 \%)$ & & \\
\hline Business group & $2(33.3 \%)$ & $4(66.7 \%)$ & & \\
\hline Salary group & $5(16.7 \%)$ & $25(83.3 \%)$ & & \\
\hline \multicolumn{3}{|c|}{ Relationship with parents } & $4.572(1)$ & 0.032 \\
\hline Good (>26) & $13(19.4 \%)$ & $86(79.6 \%)$ & & \\
\hline Poor $(\leq 26)$ & $32(24.4 \%)$ & $99(75.6 \%)$ & & \\
\hline Median $\pm S D$ & $26 \pm 3.02$ & & & \\
\hline Min-Max & $13-31$ & & & \\
\hline
\end{tabular}

than 24 were ranked under good peer norms and those who scored less than or equal to 24 from the median value were ranked under poor peer norms as shown in table 3 .

\section{DISCUSSION}

Individual factors

In this study, late youths of age 20-24 were more likely (27.8\%) to experience premarital sex than early youths (13.5\%) of age 18-19 years old. This finding was supported by the study done by Tamang (2009) who found that older students age 20 and above were more likely to have premarital sex compare to younger students aged 1519. ${ }^{4}$ However, this age relationship was inconsistent with a qualitative study done by Sujay $\mathrm{R}$ in a Delhi slum where 
several unmarried adolescents aged 13-19 years had reported some kind of sexual experience. ${ }^{1}$

Similarly, male were more likely $(16.9 \%)$ to be involved in premarital sex than female $(2.6 \%)$. This finding was corroborated with the study finding done by Sujay $\mathrm{R}$ where $15-30 \%$ of young men, and fewer than $10 \%$ of young women had premarital sex experience. ${ }^{1}$ Likewise, according to National Family Health Survey India, the national level premarital sex is still fairly low among women than men. ${ }^{5}$

Category wise urban youths were less involved in premarital sex behavior than rural youths however, among the total respondents $(n=230)$ urban youths were more involved in premarital sex behavior than rural youths $(11.3 \%$ Vs $8.3 \%)$. This finding was supported by the previous studies done by Andrew E et. al in El Salvador, where urban and male students were significantly involved in sexual risk behaviors. ${ }^{6}$ Also Study done by Makatjane P revealed that norms of the society discouraging sex before marriage have eroded more in urban areas than in rural areas. ${ }^{7}$ Therefore urban environment provides a conducive environment for experimenting with sex before marriage.

Likewise, among the total youths, youths who drink and get involved in premarital sex behavior is much higher (15.6\%) than youths who do not drink (4.0\%) but get involved in premarital sex behavior. Exactly similar finding was produced by Dahal $R$, where alcohol consumption by young men were observed to be fourfold more likely to be involved in casual sex than those who abstained from alcohol. ${ }^{8}$ Similary a study done by Zabalan ZC revealed that risk behavior such as smoking, drinking and use of drugs were all associated with higher approval of premarital sex among women and men. ${ }^{9}$

Youths having negative attitudes towards premarital sex were more likely to experience premarital sex than a positive attitude. As not much literature was accessed on the rating scale of the attitudes however, a study done by Chai Podhisita reported that male and female youths with more liberal sexual attitudes were more likely to engage in premarital sex. ${ }^{10}$

In this study other prominent variables like Grade Point Average, class level, ethnic and religion groups and marital status were not statistically significant with the premarital sex behaviours among college youths. Other studies also did not have any association with these background variables.

\section{Family factors}

Youths who had good relationship with their parents had less premarital sex experience than youths having poor relationship with their parents. A study carried out by Chai Podhisita showed that high level of family control is associated with lower risk of premarital sex, particularly for males, suggesting that control is still an effective measure if applied appropriately. ${ }^{10} \mathrm{~A}$ study done by Kamuhanda $M$ revealed that the premarital sex among Mbarara
Municipality (Uganda) secondary school adolescents of both sexes, aged 15-21 were related to the relationship with their parents. ${ }^{11}$

Youths who live together with their parents are less likely to involve in premarital sex than youths who live without parents however it was not significantly associated. The similar finding was seen in the study done by Chai Podhisita where both male and female living in intact families (with both parents) were less likely to engage in premarital sex than those in one-parent families and no-parent families. ${ }^{10}$

Youths who come from rich family were more engaged in premarital sex behaviors than youths who come from moderate to poor family ( $22.4 \%$ Vs $17.4 \%$ ) however, it was not statistically significant.

Father education had got no role either to increase or decrease premarital sex experience of their children. However, higher the mother education lowers the premarital sex experience of their children. There was a greater tendency for youth whose parents had no formal education to be involved in premarital sex compared to those whose parents had at least some formal education. ${ }^{9}$

Father and mother occupation had got no role for their children to get involved in premarital sex behaviors. However, youths of higher salary groups were negligibly less engaged in premarital sex behaviors than lower salary groups. This result was supported by the study done by Zabalan ZC found that mother's and father's occupation was negatively associated with approval rates.

\section{Peer factors}

Youths who had good peer norms were significantly less likely to experience premarital sex behaviors than youths who had poor peer norms. A study done by Chai Podhisita showed that youth who reported sexual intercourse among most of their peers have much greater exposure to premarital sex than those who reported no sexual activity among most of their friends. ${ }^{10}$ Study done by PI Okonkwo et. al found that almost half $(47.1 \%)$ of respondents indicated that they were under pressure by friends to engage in pre-marital sex, and $22.1 \%$ indicated that the pressure was moderate or severe in degree. ${ }^{12}$

\section{CONCLUSION}

One fifth of college youth had premarital sex experience where alcohol drinker had higher premarital sex experience than non-drinker. In addition youths having negative attitudes towards premarital sex were more likely to experience premarital sex than a positive attitude. Youths who had good relationship with their parents had less premarital sex experience than youths having poor relationship. And youths who had good peer norms were significantly less likely to experience premarital sex behaviors than youths who had poor peer norms 


\section{ACKNOWLEDGEMENTS}

We would like to express our sincere gratitude to all the faculties of the Department of Family Health, Mahidol University, Thailand for their continuous support and guidance for this study. In particular, we would like

\section{REFERENCES}

1. Sujay R. Premarital Sexual Behaviors Among Unmarried College Students of Gujarat, India, Health and Population Innovation Fellowship Programme Working NewDelhi; Population Council 2009:pg 9.

2. National Centre for AIDS and STD Control, Ministry of Health and Population Nepal, Fact Sheet Report 2011.

3. DiClemente RJ, Salazar LF, Crosby RA, Rosenthal SL.Prevention and Control of Sexually Transmitted Infections among Adolescents: the Importance of a Socio-ecological Perspective--a Commentary. Public Health 2005 Sep; 119(9): 825-36.

4. Adhikari R, Tamang J. Premarital Sexual Behavior among male college students of Kathmandu, Nepal. BMC Public Health 2009 Jul15;9:241.

5. Subaiya L. Premarital Sex in India: Issues of Class and Gender Delhi, National Family Health Survey-3, Economic and Political Weekly, 2008.

6. Springer AE, Selwyn BJ, Kelder SH. A Descriptive Study of Youth Risk Behavior in Urban and Rural Secondary School Students in El Salvador. BMC Int Health Hum Rights 2006 Apr :11;6-3. to acknowledge the contribution made by Preceptor, Assistant Professor Dr. Kanittha Chamroonsawasdi and Copreceptor, Associate Professor Dr. Phittaya Charupoonphol. We equally would like to acknowledge the support we received from students of several colleges.

7. Makatjane T. Pre-Marital Sex and Childbearing in Lesotho. African Population Studies 2002 ;(17)2:99-112.

8. Dahal R. Alcohol and young people in Nepal, CWIN Kathmandu 2001

9. Zablan ZC. Filipino Youth's Views on Pre-Marital Sex and Unmarried Parenthood, Manila: University of the Philippines Population Institute 2008.

10. Podhisita $C$, Xenos $P$, Varangrat $A$. The Risk of Premarital Sex among Thai Youth: Individual and Family Influences. East-West Center Working Papers. Population Series October 2001;108-5.

11. Kamuhanda M. Parental-Adolescents Relationships and premarital Sex: Parental Open Communication, Closeness and Dissaproval Relating to Adolescents Premarital Sex. LAP LAMBERT Academic Publishing January 2012.

12. PI Okonkwo, AO Fatusi, AL Ilika. Perception of Peers' Behaviour regarding Sexual Health Decision Making among Female Undergraduates in Anambra State, Nigeria. African Health Sciences 2005;5(2):107-113. 